\title{
Analisa Kekuatan Memanjang Floating Dock Konversi Dari Tongkang dengan Metode Elemen Hingga
}

\author{
Dwi Rendra Pramono, Asjhar Imron, \& Mohammad Nurul Misbah \\ Jurusan Teknik Perkapalan, Fakultas Teknologi Kelautan, Institut Teknologi Sepuluh Nopember (ITS) \\ Jl. Arief Rahman Hakim, Surabaya 60111 Indonesia \\ e-mail: aimron@na.its.ac.id \& mnmisbah@na.its.ac.id
}

\begin{abstract}
Abstrak-Tugas Akhir ini bertujuan untuk mengetahui kekuatan memanjang dari floating dock yang merupakan hasil konversi dari tongkang dengan panjang $91.3 \mathrm{~m}$ dengan mengacu pada kriteria untuk kekuatan memanjang yang telah ditentukan oleh BKI (Biro Klasifikasi Indonesia). Pengecekan harga tegangan dilakukan pada tiga kondisi pembebanan yaitu (1) kondisi muatan kosong, (2) kondisi floating dock tercelup, dan (3) kondisi muatan penuh dengan ada kapal docking diatasnya (kondisi kerja). Analisa dilakukan menggunakan program Finite Element Analysis (FEA) dengan membuat pemodelan keseluruhan floating dock dan pembebanannya. Pemodelan struktur berdasarkan data construction profile dan pemodelan dilakukan dengan surface model untuk pelat, penumpu dan line model untuk penegar. Kondisi batas menggunakan 3-2-1 Minimal Supports berdasarkan Guideline DNV-GL. Hasil dari pemodelan dilakukan validasi dengan uji konvergensi. Dari hasil analisa tersebut didapatkan deformasi sebesar $19.955 \mathrm{~mm}$ dan tegangan max sebesar 78.827 MPa untuk kondisi muatan kosong, deformasi sebesar $21.572 \mathrm{~mm}$ dan tegangan max sebesar 196.34 MPa untuk kondisi floating dock tercelup, deformasi sebesar $18.189 \mathrm{~mm}$ dan tegangan max sebesar 137.54 MPa untuk kondisi kerja. Kekuatan memanjang floating dock telah terpenuhi karena hasil tegangan pada kondisi kerja sebesar $137.54 \mathrm{MPa}$ lebih kecil daripada tegangan izin yaitu sebesar $160 \mathrm{MPa}$ dan tegangan pada kondisi muatan kosong sebesar 78.827 MPa lebih kecil daripada tegangan izin yaitu sebesar 120 MPa. Meskipun pada kondisi tercelup tegangan yang dihasilkan tidak memenuhi aturan dari klas namun hasil tersebut dapat diterima karena kondisi tersebut hanya terjadi sesaat pada kondisi nyata floating dock dan harga tegangan sebesar 196.34 MPa tersebut tidak melebihi yield strength dari material yang digunakan yaitu sebesar 235 MPa.
\end{abstract}

Kata Kunci-Deformasi, Floating Dock, Kekutan Memanjang, Tegangan

\section{PENDAHULUAN}

$\mathrm{K}$ EBUTUHAN akan alat transportasi laut adalah hal yang mutlak untuk dilaksanakan. Kebutuhan ini terlihat dari kebutuhan untuk mengangkut berbagai macam muatan dari sumber daya alam hingga logistik. Transportasi laut yaitu kapal memiliki kelebihan dalam hal daya tampung muatannya yang sangat besar. Terlebih di negara kepulauan seperti Indonesia cara untuk melakukan pendistribusian berbagai macam mutan seperti logistik ke berbagai pulau tidak lain adalah dengan menggunakan kapal. Namun seperti halnya kendaraan darat maupun udara kendaraan laut juga memiliki kemungkinan mengalami kerusakan selama penggunaannya.
Oleh karena itu kebutuhan akan tempat untuk melakukan reparasi kapal pun akan ikut meningkat seiring jumlah kapal yang bertambah. Galangan merupakan tempat yang digunakan baik untuk mereparasi kapal maupun membangun kapal baru. Berbagai macam sarana pengedokanpun dibutuhkan sebagai tempat untuk melakukan proses reparasi kapal. Salah satu sarana pengedokan adalah floating dock yang memiliki kelebihan dalam hal kemudahan untuk mengedokkan kapal karena dapat diapungkan dan ditenggelamkan sesuai kebutuhan pengedokan dan dapat dipindah tempat juga sesuai kebutuhan (portable). Namun sebagai bangunan yang terapung floating dock memiliki kekurangan jika dibandingkan dengan alat pengedokan yang bersifat permanen seperti graving dock yaitu kemungkinan rusaknya floating dock itu sendiri baik akibat berbagai macam peralatan yang ada diatasnya maupun akibat kapal yang akan docking di floating dock tersebut. Karena itu perlu adanya peninjauan terhadap kekuatan memanjangnya (longitudinal strength), yang dalam hal ini dipengaruhi oleh distribusi muatannya yang merupakan tekanan internal dari muatan floating dock itu sendiri beserta kapal yang berada di atasnya. Terlebih apabila floating dock memiliki panjang yang melebihi 65 meter maka diperlukan adanya pengecekan kekuatan memanjang yang juga terdapat aturannya dalam klas.

Dalam tugas akhir ini akan dibahas bagaimana mengetahui seberapa besar pengaruh beban internal berupa muatan dan peralatannya serta pembebanan yang terjadi. Selain itu juga akan dilakukan analisa kekuatan memanjang dari floating dock yang merupakan konversi dari kapal tongkang. Floating dock yang umumnya direncanakan menggunakan ponton baru dalam tugas akhir ini floating dock merupakan tongkang yang sudah tidak terpakai dan dikonversi menjadi floating dock sehingga perlu adanya pengecekan ulang kekuatan memanjang karena kondisi pembebanan yang berbeda dari tongkang yang menjadi floating dock. Dengan analisis beban yang terjadi akibat pengaruh beban floating dock dapat diketahui kekuatan minimum yang dibutuhkan. Terlebih beban yang berbeda dari setiap kapal yang akan melakukan docking juga menjadi pertimbangan perlunya dilakukan pengecekan kekuatan memanjang dari floating dock tersebut agar tidak terjadinya kegagalan struktur di masa mendatang. Tugas akhir ini menggunakan metode elemen hingga (FEM) dalam analisa tegangan yang dialami oleh floating dock tersebut. 


\section{DASAR TEORI}

\section{A. Pengertian Floating Dock}

Floating Dock adalah suatu bangunan konstruksi di laut yang digunakan untuk Pengedockan kapal dengan cara menggelamkan dan mengapungkan dalam arah vertikal. Konstruksi floating dock ini umumnya terbuat dari baja dan plat, di mana sumber istrik penyuplainya dapat digolongkan menjadi dua yaitu: suplai listrik dari darat atau dari floatingnya sendiri. Salah satu hal yang paling tampak dari floating dock ini adalah kemampuannya Untuk mereparasi pontonya sendiri (self dockijng).

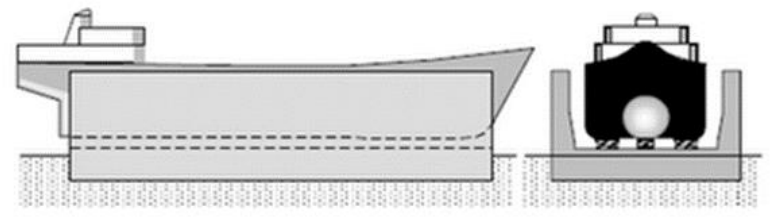

Gambar 1. Floating Dock (sumber: http ://desainkapal.wordpress.com)

\section{B. Kekuatan Memanjang Kapal}

Longitudinal strength atau kekuatan memanjang adalah perhitungan kekuatan kapal secara memanjang kapal untuk menopang beban muatan dan beban kapal itu sendiri ketika berlayar pada kondisi air tenang maupun bergelombang. Longitudinal strength menjadi salah satu persyaratan klasifikasi (class) untuk kapal-kapal dengan panjang lebih dari $65 \mathrm{~m}$. Perhitungan ini tergantung pada ukuran kapal dan scantling (ukuran profil dan plat) yang digunakan di kapal. Scantling inilah yang selanjutnya dihitung inersianya untuk mendapatkan besarnya tegangan dan momen yang dialami kapal karena beban muatan dan gelombang. Dalam pasal ini dianggap bahwa lengkung distribusi gaya berat kapal dan lengkung distribusi gaya tekan keatas sepanjang kapal dapat memenuhi syarat keseimbangan kedua yaitu titik pusat gaya berat dan titik pusat gaya tekan keatas terletak disatu garis vertikal (satu garis kerja).

1) Penyebaran Gaya Berat:

$w(x)=g \cdot m(x)$

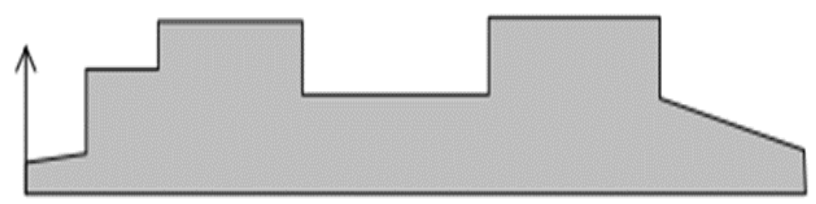

Gambar 2. Distribusi Gaya Berat

2) Penyebaran Gaya Tekan Keatas:

$$
\mathrm{b}(\mathrm{x})=\rho \cdot g \cdot \mathrm{a}(\mathrm{x})
$$

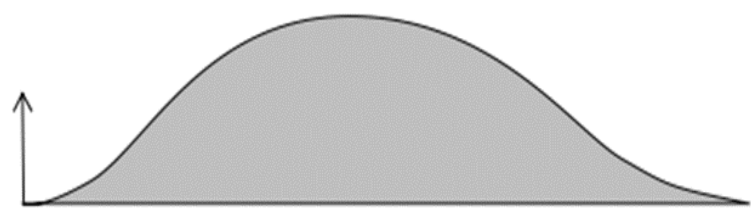

Gambar 3. Distribusi Gaya Angkat
Ruas kanan merupakan distribusi memanjang dari bebanbeban yang bekerja pada kapal. Dan $f(x)$ merupakan selisih antara gaya tekan keatas dan gaya berat. Jika lengkung diagram gaya berat kita kurangi dengan lengkung diagram gaya tekan keatas, akan diperoleh lengkung penyebaran beban sepanjang kapal:

$$
f(x)=b(x)-w(x)
$$

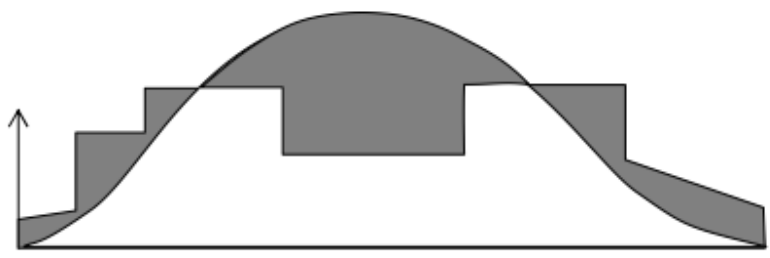

Gambar 4. Superposisi Gaya Angkat dan Gaya Berat

dan beban $f(x)$ ini merupakan turunan kedua dari momen lengkung:

$$
f(x)=\frac{d^{2} M}{d x^{2}}
$$

Besar gaya lintang adalah lengkung integral pertama dari beban $f(\mathrm{x})$, oleh karena itu persamaan gaya lintang dapat kita peroleh dari [1]:

$$
Q(x)=\int_{o}^{x} f(x) d x
$$

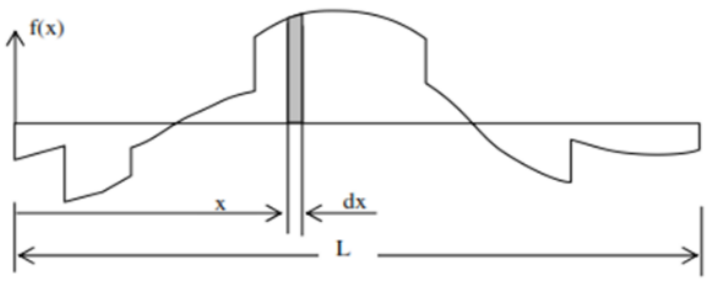

Gambar 5. Gaya lintang

\section{Metode Elemen Hingga}

Metode elemen hingga merupakan metode numerik yang digunakan untuk menyelesaikan permasalahan dalam bidang rekayasa seperti geometri, pembebanan dan sifat-sifat dari material yang sangat rumit. Hal ini sulit diselesaikan dengan solusi analisa matematis. Pendekatan metode elemen hingga adalah menggunakan informasi-informasi pada titik simpul (node). Dalam proses penentuan titik simpul yang di sebut dengan pendeskritan (discretization), suatu sistem dibagi menjadi bagian-bagian yang lebih kecil, kemudian penyelesaian masalah dilakukan pada bagian-bagian tersebut dan selanjutnya digabung kembali sehingga diperoleh solusi secara menyeluruh.

Kini sangatlah memungkinkan untuk menggunakan program computer untuk melakukan analisa dengan metode elemen hingga yang dikenal dengan FEA (finite element analysis). Dengan adanya metode ini dapat dilakukan analisa keseluruhan badan kapal secara utuh. Tujuan dari penggunaan metode elemen hingga ini adalah untuk mendapatkan perhitungan yang 
akurat terhadap respon tegangan dari kapal. Beberapa tingkatan dalam pemodelan elemen hingga dapat digunakan dalam analisis seperti berikut:

- Global stiffness model

- Cargo hold model

- Frame and girder model

- Local structure model

- Stress concentration model

dalam pengerjaan tugas akhir ini jenis/tingkat model elemen hingga yang digunakan adalah global stiffness model [2].

\section{METODOLOGI}

Dalam tugas akhir ini akan dilakukan pemodelan dan analisis dari kekuatan memanjang menggunakan metode elemen hingga. Bagian ini merupakan inti dari tugas akhir ini dan merupakan bagian yang memakan waktu paling lama dalam pengerjaan tugas akhir. Pemodelan dilakukan secara global dengan menggunakan FEA software. Hasil dari pemodelan ini adalah mendapatkan harga tegangan dan defleksi dari floating dock yang diteliti dengan tiga macam kondisi pemuatan.

Lambung/ badan dari floating dock dimodelkan berdasarkan drawings yang didapatkan dari galangan kapal terkait. Setelah model selesai dibuat maka diberikan kondisi batas (boundary constrain) dan pembebanan sesuai kondisi pemuatan yang ada. Lalu hasil dari harga tegangan maksimum yang diperoleh dari pemodelan dibandingkan dengan tegangan yang diizinkan oleh class.

\section{A. Model}

Pemodelan floating dock dalam pengerjaan tugas akhir ini dilakukan dengan bantuan program FEA. Model dibuat dengan $3 D C A D$ software sebelum nantinya akan dilakukan pendiskritan model menjadi elemen-elemen yang lebih kecil.

Pelat dan Penumpu (Girder) dimodelkan dengan 2D surface yaitu berupa luasan yang memiliki ketebalan tertentu.Penegar dimodelkan dengan 1D line yang memiliki cross section. Bracket dan lubang-lubang kecil tidak dimodelkan untuk mempermudah proses pembuatan geometri [3].

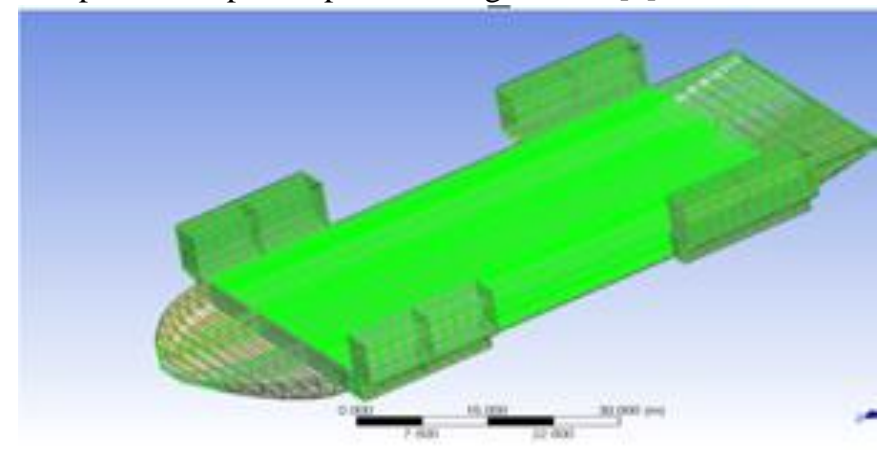

Gambar 6. Full Model Floating Dock

\section{B. Meshing}

Meshing adalah suatu proses dalam FEA untuk membagi keseluruhan sistim menjadi elemen-elemen yang lebih kecil untuk didapatkan analisa yang detail pada keseluruhan sistim tersebut. Dalam FEA software yang digunakan hanya ada tiga jenis elemen utama yang dapat digunakan dan terpilih secara otomatis tergantung bagaimana model yang dibuat. Tiga jenis elemen tersebut adalah:

1) Shell Element- terpilih secara otomatis apabila model dibuat dengan menggunakan surface

2) Beam Element- terpilih secara otomatis apabila model dibuat dengan menggunakan line yang memiliki cross section

3) Solid Element- terpilih secara otomatis apabila model dibuat dengan menggunakan solid

Dalam tugas akhir ini yang digunakan adalah surface dan line maka elemen yang digunakan adalah shell element (shell 181) dan beam element (beam 188.) [4]. Elemen-elemen inilah yang umum digunakan untuk analisa pada bidang perkapalan.

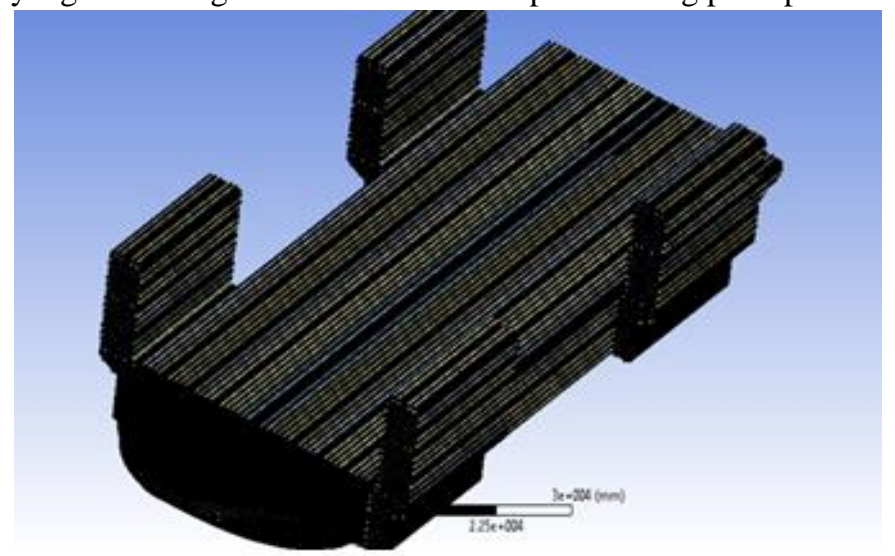

Gambar 7. Full Model Mesh

\section{Kondisi Batas}

Kondisi batas yang digunakan dalam tugas akhir ini adalah 3-2-1 Minimal Supports. Yang dimaksud dengan 3-2-1 Minimal Supports adalah suatu metode yang umum digunakan pada FEA khususya analisa linier statis untuk mendapatkan hasil yang realistis. Setelah memastikan bahwa beban sudah diaplikasikan dengan benar atau dengan kata lain seimbang maka langkah berikutnya adalah memberika tumpuan. Tumpuan yang digunakan pada 3-2-1 Minimal Supports berjumlah tiga buah titik. Tiga buah titik yang digunakan ini merepresentasikan sebuah bidang pada 3 dimensi namun bukan berupa tiga buah titik pada satu garis lurus. Bidang apa saja yang akan digunakan tidak menjadi masalah tergantung dari kebutuhan.

Tiga buah kondisi batas terbagi menjadi dua buah diletakkan pada bagian belakang kapal dan satu buah diletakkan pada bagian depan kapal. Titik pertama diletakkan di belakang dan pada starboard dengan derajat kebebasan yang dikunci (fixed) adalah arah $\mathrm{x}, \mathrm{y}$, dan $\mathrm{z}$ untuk menghilangkan tiga buah translasi. Kemudian titik kedua diletakkan sejajar dengan titik pertama pada portside dengan koordinat $\mathrm{x}$ yang berbeda namun koordinat y dan $\mathrm{z}$ tetap sama. Pada titik kedua ini derajat kebebasan yang dikunci (fixed) adalah arah y dan z untuk menghilangkan rotasi terhadap $\mathrm{z}$ dan y namun masih terdapat rotasi terhadap sumbu $\mathrm{x}$. Terakhir adalah titik ketiga yang diletakkan pada bagian depan kapal pada centerline dan derajat kebebasan yang dikunci (fixed) adalah arah y untuk menghilangkan rotasi terakhir yaitu rotasi terhadap sumbu $\mathrm{x}$ [5]. 


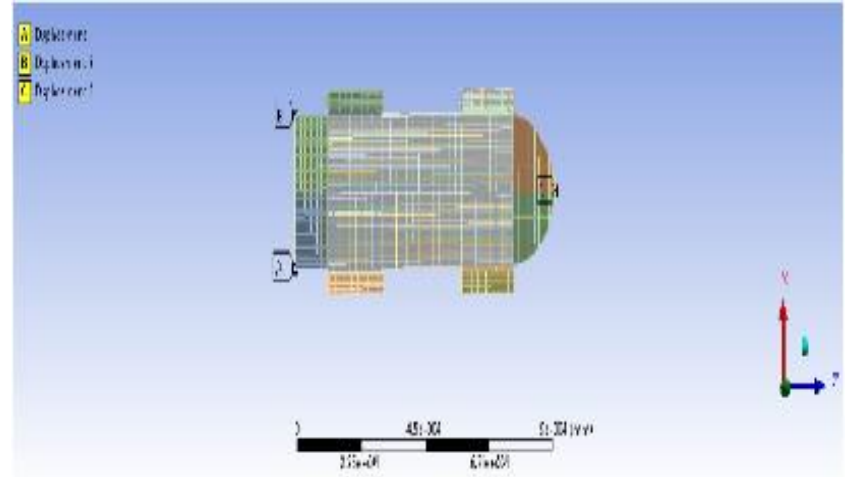

Gambar 8. Kondisi Batas

\section{Pembebanan}

Jenis beban yang digunakan dalam analisa ini adalah:

1) Berat baja dan tangki (gravity load)

2) Hydrostatic pressure

Pembebanan diberikan dalam bentuk tekanan pada surface.

\section{HASIL DAN PEMBAHASAN}

\section{A. Variasi Kondis Pembebanan}

Dalam tugas akhir ini terdapat tiga buah kondisi pembebanan yang dilakukan analisis menggunakan metode elemen hingga untuk mendapatkan respon utama yaitu berupa deformasi/defleksi dan tegangan secara memanjang. Berikut ini adalah tiga buah variasi kondisi pembebanan yang digunakan:

1) Load Case 1: adalah kondisi pembebanan di mana floating dock berada pada kondisi normal yaitu mengapung tanpa ada muatan diatasnya. Beban yang bekerja hanya berupa berat dari floating dock itu sendiri dan buoyancy yang bekerja pada lambung floating dock pada sarat $6.5 \mathrm{~m}$. Merupakan pembebanan yang paling aman atau dengan kata lain tidak buruk.

2) Load Case 2 : adalah kondisi pembebanan di mana floating dock berada pada kondisi tercelup (immersing condition) yaitu seluruh lambung floating dock tercelup hingga geladak dan yang tersisa hanya safety deck (working deck) dari wing tank yang tidak tercelup. Beban yang bekerja adalah berat dari floating dock itu sendiri, berat dari tangkitangki, dan buoyancy yang bekerja pada lambung kapal pada sarat $11.8 \mathrm{~m}$. Merupakan pembebanan yang paling buruk.

3) Load Case 3 : adalah kondisi pembebanan di mana floating dock berada pada kondisi bekerja yaitu mengapung dengan adanya muatan berada diatasnya. Beban yang bekerja adalah berat dari floating dock itu sendiri, berat dari tangkitangki, dan buoyancy yang bekerja pada lambung floating dock pada sarat $5 \mathrm{~m}$. Merupakan pembebanan yang diminta oleh class society untuk dihitung dengan batasan tegangan maksimum tertentu.

\section{B. Konvergensi}

Konvergensi adalah salah satu cara yang digunakan untuk melakukan pemilihan ukuran elemen yang tepat dalam pembuatan model elemen hingga sehingga model menghasilkan nilai yang valid. Konvergensi dilakukan dengan melakukan perbandingan dari beberapa ukuran dan jumlah elemen pada satu model. Adapun hasil tegangan dan deformasi dari konvergensi model dapat dilihat dalam tabel berikut.

Tabel 1.

Hasil Konvergensi

\begin{tabular}{cccc}
\hline \hline No & Jumlah Elemen & Deformasi (mm) & Tegangan (MPa) \\
\hline 1 & 679505 & 19.933 & 78.232 \\
2 & 753076 & 19.936 & 78.827 \\
\hline \hline
\end{tabular}

Tabel 2.

Persentase Konvergensi

\begin{tabular}{ccccc}
\hline \hline \multirow{2}{*}{ No } & \multirow{4}{c}{ Output } & Elemen & Elemen & \multirow{2}{*}{ Persentase } \\
& & 753076 & 679505 & \\
\hline 1 & Deformasi & 19.933 & 78.232 & $0.02 \%$ \\
2 & Tegangan & 19.936 & 78.827 & $0.75 \%$ \\
\hline \hline
\end{tabular}

\section{Hasil}

Setelah dipastikan bahwa model sudah memenuhi uji konvergensi maka model tersebut digunakan untuk melakukan analisa dari berbagai variasi kondisi pembebanan. Setelah semua pembebanan dan kondisi batas telah diaplikasikan pada model, maka langkah selanjutnya adalah melakukan running dari pemodelan tersebut dan menganalisa hasil dari pemodelan tersebut.

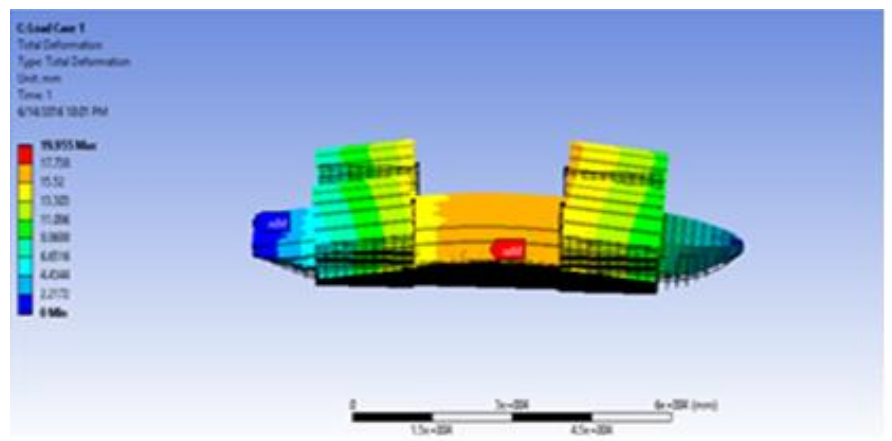

Gambar 9. Total Deformation Load Case 1

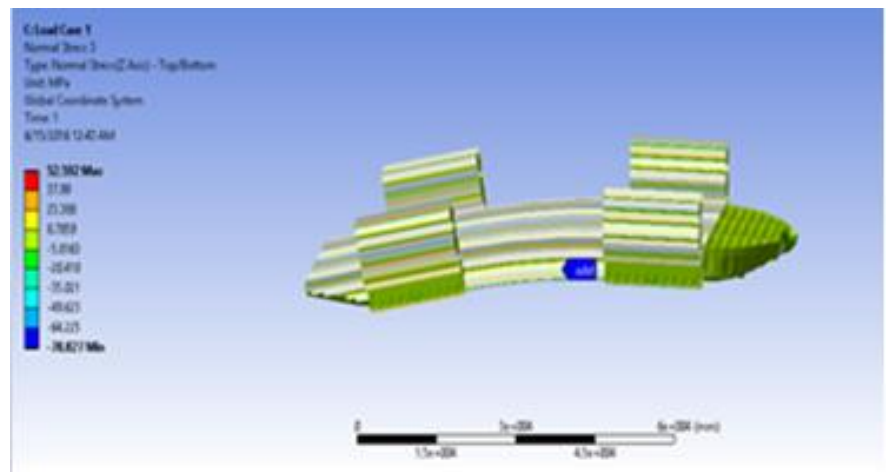

Gambar 10. Stress Load Case 1 


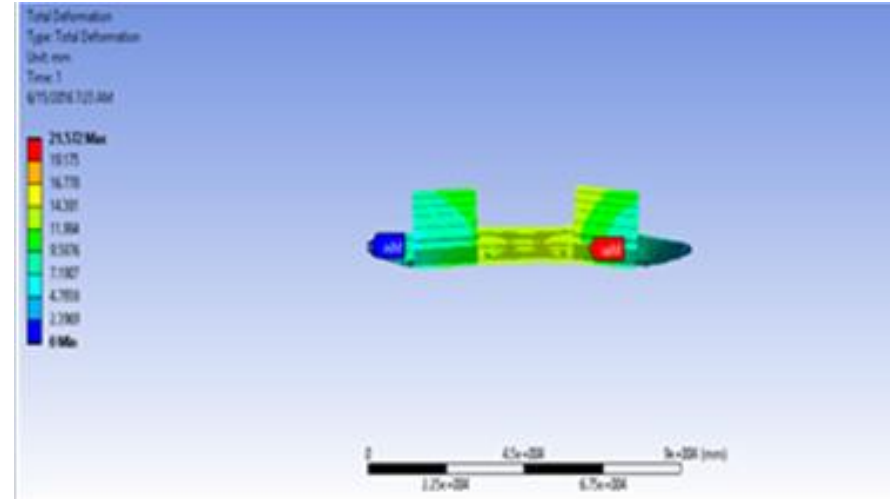

Gambar 11. Total Deformation Load Case 2

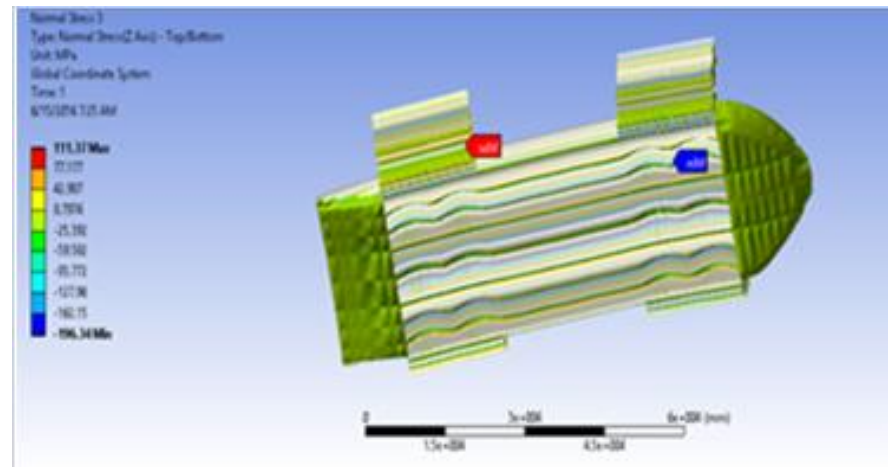

Gambar 12. Stress Load Case 2

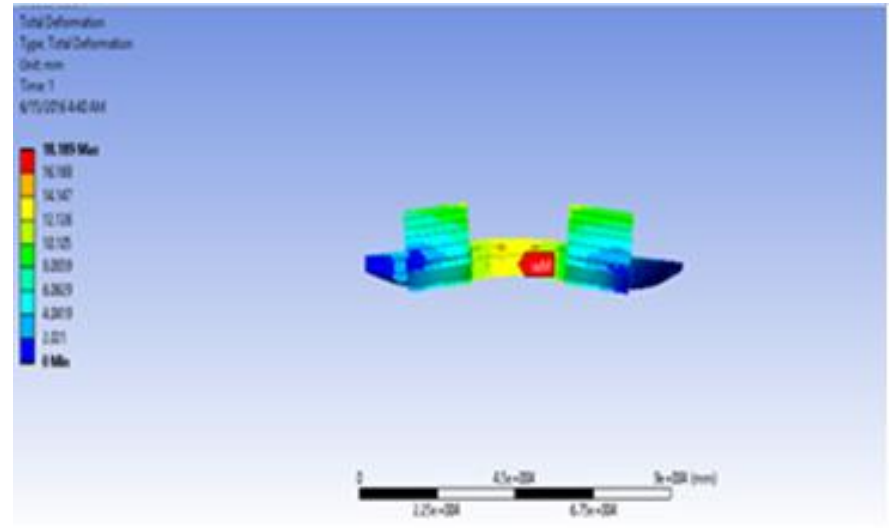

Gambar 13. Total Deformation Load Case 3

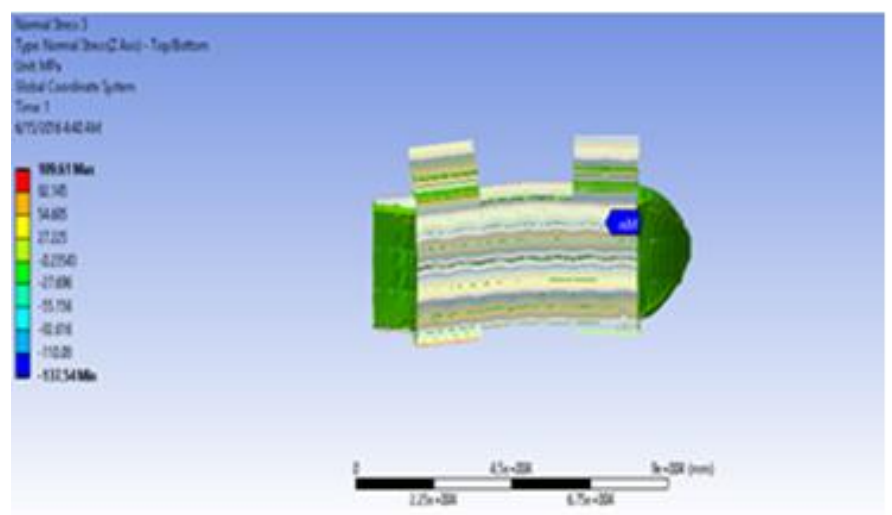

Gambar 14. Stress Load Case 3

\section{KESIMPULAN}

Berdasarkan pemodelan pembeban floating dock yang telah dilakukan, maka dapat diambil kesimpulan sebagai berikut:

1) Deformasi maksimum yang dialami floating dock dalam ketiga kondisi pembebanan terjadi pada daerah parallel middle body dengan harga masing-masing secara berurutan sebesar $19.955 \mathrm{~mm}, 21.572 \mathrm{~mm}$, dan $18.189 \mathrm{~mm}$.

2) Tegangan maksimum yang dialami floating dock dalam ketiga kondisi pembebanan terjadi pada daerah parallel middle body pada bagian alas dengan harga masing-masing secara berurutan sebesar 78.827 MPa, 196.34 MPa, dan $137.54 \mathrm{MPa}$

3) Kekuatan memanjang dari floating dock memenuhi aturan BKI karena tegangan pada load case 2 berharga lebih kecil dibandingkan tegangan maksimum yang diizinkan yaitu 137.54 MPa (tegangan izin $160 \mathrm{MPa}$ ). Load case 2 menjadi acuan karena merupakan pembebanan yang dialami floating dock dalam waktu yang lama dibandingkan loading case lainnya.

4) Harga tegangan pada kondisi load case 3 masih dapat diterima meskipun lebih tinggi harganya dibandingkan tegangan izin yaitu 196.34 MPa karena kondisi tersebut hanya dialami sesaat oleh floating dock dan masih berada di bawah yield strength dari material yaitu $235 \mathrm{MPa}$.

\section{DAFTAR PUSTAKA}

[1] A. Ben and E. T. Diego, "Analytical and Numerical Determination of The Hull Girder Deflection of Inland Navigation Vessels," Master Thesis: Polytechnic University of Cartagena, Cartagena, 2015.

[2] DNV-GL, Class Guidline - Finite Element Analysis, 2015.

[3] Anonim, "Finite Element Method (FEM) Analysis," Desain Kapal, [Online]. Available: https://desainkapal.wordpress.com/2011/03/30/finite-element-methodfem-analysis/. [Accessed 2 September 2015].

[4] H. H. Lee, Finite Element Simulations with ANSYS Workbench 14, USA, 2012.

[5] B. Santosa, "Diktat Kekuatan Kapal," Institut Teknologi Sepuluh Nopember, Surabaya, 2013. 